\title{
Filmid Eesti Rahva Muuseumi püsinäitusel „Kohtumised"
}

\section{Karin Leivategija}

\section{Sissejuhatus}

Käesolev artikkel uurib ja kirjeldab filmi kasutamise meetodeid ja eesmärke Eesti Rahva Muuseumi pühinäitusel „Kohtumised“. Artikkel toob välja erinevaid antropoloogilisele filmile omaseid lähenemisi, mis toetavad näituse üht olulist eesmärki anda külastajale võimalus iseseisvalt kogeda ja mõtestada näituse sisu.

Filmi on etnograafilistel näitustel kasutatud juba 20. sajandi algusest peale. Esimest spetsiaalselt näituse jaoks valminud filmi eksponeeriti Ameerika Loodusmuuseumis 1930. aastal (Griffiths 2013: 90). Eksponeeritud filmide sisuks on traditsiooniliselt olnud välitööde käigus kogutud antropoloogiline filmimaterjal, mis pandi esemete kõrvale näitusele välja (Jørgensen 2018). ${ }^{1}$ 1960. aastatel hakkas ka ERM välitööde käigus filmimaterjali tootma ning see sai tänu direktor Aleksei Petersonile muuseumi üheks põhitegevuseks (Toulouze ja Niglas 2009: 102). Samas on ERMi eelmisel püsinäitusel nende filmide kasutamine olnud marginaalne. 
Petersoni eestvedamisel tehtud filmid, mis käsitlevad enamasti talurahva kultuuri ja töövõtteid, on rangelt üldistavad ja didaktilised konstruktsioonid, mida saadab autoritekst. Sel moel järgisid teosed mitmeti tol perioodil läänemaailmas visuaalantropoloogide kasutatud meetodeid, mis välistasid võimaluse, et vaataja saaks filmi iseseisvalt mõtestada. Antropoloogide-filmitegijate eetiline probleem on kogu aeg olnud oma töö kontekstualiseerimine, et pärast filmi avaldamist akadeemilise kontrolli alt väljunud teos ei tekitaks konteksti mittetundvas vaatajas n-ö valesid järeldusi. Nii kujunes antropoloogilisest filmist möödunud sajandi keskpaigaks David MacDougalli (1997: 290) sõnade järgi „järeleandmatult didaktiline“ meedium, mis sarnanes „illustreeritud loenguga“. Kaadritaguse selgitava teksti või kirjaliku infoga hoiti visuaalantropoloogiat turvaliselt professionaalse kontrolli all.

Nii visuaalantropoloogia kui ka museoloogia huvituvad objektiivse tõe esitamise ja subjektiivse kogemise suhtest ning selle muutumise uurimisest. Nii nagu muuseumid on traditsiooniliselt hoidnud võimu teadmiste loomisel ja jätnud külastaja kureeritud materjali passiivse vastuvõtja rolli (Runnel jt 2014: 206), on seda teinud ka antropoloogiline film.

Teadmised ei eksisteeri aga objektiivse reaalsusena, vaid neid luuakse aktiivse arutelu kaudu informandi ja uurija vahel (Pink 2007: 98). Sellist arutelu, kus teadmisi luuakse dialoogis, soovitakse tänapäeval tekitada ka muuseumi ja külastaja vahel. Arusaamad teadusliku ja humanistliku teadmise objektiivsuse võimalikkusest on vananenud ning see on julgustanud muuseume üha enam keskenduma üksikisiku subjektiivsele kogemusele (Henning 2005: 92).

ERMi püsinäitus „Kohtumised“ soovib külastajale pakkuda vabadust nähtut ja kogetut iseseisvalt tõlgendada. Nii on distantseerutud iganenud traditsioonist luua rangelt didaktilist ja universaalset tähendust kandvat näitust. Keskseks mõisteks on dialoogilisus (Rattus 2016: 146), mis ajendab külastajat näitust aktiivselt tõlgendama. Dialoogilisuse all ei ole silmas peetud kahepoolset verbaalset interaktsiooni, vaid see avaldub näitusel erinevate vaadete kõrvutamise kaudu (samas: 150).

Nii nagu ERMi üks eesmärk on olla n-ö kaasav foorum autoritaarse templi asemel (Cameron 1971; Delgado 2009: 8), täidavad ka filmid dialoogivõimaluse looja rolli näitusekülastajate ja muuseumi ning muuseumi ja ühiskonna vahel. 
Nii nagu näitusekuraator peab ka filmitegija langetama keerukaid otsuseid, mis puudutavad lugude ja inimeste representeerimist. Samas on suurte lugude jutustamiseks võimalik kasutada vaid fragmente ese, filmimaterjal, foto, tekst, mida saab veel omakorda lõputul moel kureerida või monteerida.

Otsustamise tulemusel jäävad materjali tohutud ajalised, ruumilised ja detaile puudutavad lüngad ning need muutuvad sama kõnekaks kui materjal, mida tegelikult näidatakse. Kui jätta kõrvale tõsiasi, et on absurdne üritada maailma selle kõikides perspektiivides ja detailides täpselt jäljendada, siis annavad need lüngad [...] vaatajale loomingulise rolli autori esitatud fragmentide kokku sulatamisel. (MacDougall 2006: 34)

Püsinäitusele „Kohtumised“ loodud filmide seas leidub nii dokumentaalfilme, mis rakendavad tänapäevase loomingulisemat lähenemist ja interpreteerimisvõimaluste paljusust pooldava visuaalantropoloogia meetodeid kui ka ajalooliste sündmuste lavastusi, mis põhinevad eri tüüpi arhiiviallikatel. Filmid täidavad näitusesaalis mitmekülgseid eesmärke, olles enamat kui pelgalt illustreerivad, meelelahutust pakkuvad või näitusel õpitud fakte kinnistavad vahendid.

Eri näo ja otstarbega näitusefilmid on lõimitud nii näituse alateemadega üldisemalt kui ka konkreetsete eksponaatidega. Suurem osa ekraane on vertikaalses asendis (foto 6), mis mõjuvad näitusekülastajale potentsiaalselt värskendavalt ning loovad koosmängus vitriinidega ühtse visuaalse rütmi. Filmid ei ole peidetud seinte taha ega summutatud kõrvaklappidega, vaid on pandud selgesse suhtesse ümbritsevate esemete ja puutelaudadega, millest mitmed kutsuvad külastajat muuseumile oma kogemusi jagades sisu looma.

Foto 6

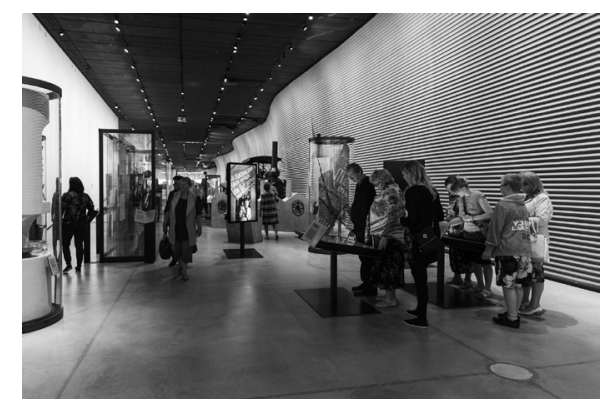


Suurem osa audiovisuaalsest materjalist on toodetud spetsiaalselt „Kohtumiste“ jaoks. Neid on kureerinud muuseumiprofessionaalid koostöös filmitootmisfirmaga Allfilm eesotsas režissöör Marko Raadiga. Käesolevas artiklis vaatlen ja analüüsin nii enda installatiivset videoeksponaati „Vabaduste lood“ kui ka valikut Marko Raadi filmidest, mis näitlikustavad eesmärke ja rolle, mis saab filmil näituseruumis olla.

\section{Vabaduste lood}

Videoeksponaat „Vabaduste lood“ on mittemateriaalseid teemasid käsitlev ja subjektiivseid vaatenurki esitav kumulatiivne jutustus vabadusest. Vabadust kui abstraktset, kuid olemuslikult üldinimlikku ideed on esitletud 74 paariminutilise videoklipi kaudu, mis on tehtud tänapäeva Eesti inimestega. „Vabaduste lood“ on eksponeeritud näituse nüüdisaega käsitlevas osas, mis on võtnud vabaduse teema fookusse tänapäevast rääkimisel. See on eraldiseisev eksponaat, millega ei ole väljapandud esemeid otsesesse seosesse sätitud, kuid sisu poolest on see ümbritseva ekspositsiooniga läbi põimunud. ${ }^{2}$

„Vabaduste lugude“ jaoks filmisin ja monteerisin materjali 2014. aasta suvest kuni ERMi uue hoone valmimiseni 2016. aasta sügisel. Informantide näol oli tegemist tavaliste Eestis elavate inimestega, kellest vähestel oli eelnev kaamera ees rääkimise kogemus. Intervjuuküsimustik oli poolstruktureeritud ning varieerus vastavalt iga informandi loole. Intervjueeritavatel oli võimalus valida fookus ja viis, kuidas vabadusest rääkida. Palusin informantidel muu hulgas kirjeldada, mis on nende jaoks vabadus, ning tuua välja olukordi, kus nad on tundnud, et nende vabadust piiratakse. Samuti huvitas mind, kuidas informandid hindasid vanemate ja nooremate põlvkondade vabadusi ja nende puudumist. Kokku tegin Eestis elavate erinevast sotsiaalsest, kultuurilisest ja ealisest grupist pärit inimestega 74 filmitud intervjuud, mis on videoportreede ja kirjalike tsitaatide näol „Kohtumistel“ eksponeeritud. Valim kujunes töö käigus ning selle loomisel kasutasin isiklikke ja erialaseid kontakte ning sotsiaalmeediat. Projekti alguses oli oluline kriteerium informandi leidmisel tema valmisolek rääkida kaamera ees ning hea eneseväljendusoskus. Projekti edenedes hakkasin enam tähelepanu pöörama ealisele, geograafilisele, sotsiaalsele ja kultuurilisele mitmekesisusele ja soolisele tasakaalule ning otsima informante sellest lähtuvalt.

2 Vabadusega seoses räägivad informandid muu hulgas religiooni-, väljendus-, tarbimis- ja liikumisvabadusest ning vabaduse võtmisest need teemad on „Kohtumistel“ mitmekülgselt esindatud ka esemete, filmide ja puutelaudade kaudu. 
Vabadus on abstraktne kontseptsioon, millega igal inimesel on isiklik suhe. Eksponaadi etikett on inspireeritud hulgast sotsiaalsetest, ajaloolistest ja filosoofilistest ideedest, mida intervjueeritavad avaldasid:

Vabaduse all peetakse muu hulgas silmas võrdsust, materiaalset sõltumatust, privaatsust, võimalust valida, öelda ja ise otsustada ning õigust olla teistsugune. Vabaduste puudumine võrdsustatakse näiteks haiguste, kuritegevuse, üksinduse, töö, sõltuvuste, regulatsioonide ning piirangutega. Osa inimesi arvab, et oleme vabad niikaua, kuni meie mõtted on vabad, kuid teised usuvad, et täielikku vabadust ei ole olemas. Kui üks inimene on Siberis suutnud tunda puhast vabadusejoovastust, siis teise jaoks on praegune Eesti ühiskond rõhuv ja tugevalt vabadusi piirav. Ühe jaoks toob vabaduse võimalus jumalasõna juba varases lapseeas tundma õppida, kuid teise jaoks võtab religioon vabaduse ise oma elu üle otsustada. Kui ühe jaoks võivad vabas riigis üksteise kõrval elada erineva rassilise tausta ja seksuaalse suundumusega inimesed, siis teiselt võtab see võimaluse end vabalt tunda. Kui tarbimine, õppimine ja töötamine on ühe jaoks võimalus, siis teise jaoks on see vastupidi hoopis sundus. (Leivategija 2016)

„Vabaduste lood“ vaatleb, kuidas tänapäeva Eesti inimesed mõtestavad lähiajaloos aset leidnud sündmusi, isiklikku elukogemust ja ka tänapäeva ühiskonna sotsiaalseid kitsaskohti ning inimeste suhtumist keerukatesse ja ühiskonda polariseerivatesse teemadesse. Mõne vabaduse narratiiviga suhestub enamik eestlasi, näiteks lugudega sõdadest, küüditamistest, okupatsioonidest ja iseseisvusest. Mitmed teemad võivad aga oma keerulise olemuse tõttu tekitada muuseumi külastajates lahkarvamusi. Vastuseis kipub tänapäeval tekkima eelkõige integratsiooni, immigratsiooni, religiooni ja LGBT teemasid käsitledes. Lisaks maailmavaatelisele opositsioonile külastaja ja intervjueeritava vahel võib toimuda vastandlikke tõekspidamisi esitav diskussioon ka informantide lugude kõrvutamisel. Näiteks on eksponaadis esitletud kahe noore eestlase arvamusavaldused, mis asetavad multikultuursuse teema nende enda isikliku vabaduse konteksti, väljendades samas nende diametraalselt erinevaid vaateid.

J: Ma ei ole rassist, aga ma leian, et meie väike rahvas on küll siuke, mida peaks nagu rohkem natuke hoidma ja kaitsma. [...] Aga multikultuursust ma näiteks ei tahaks oma rahvale. See on natuke keerulisem teema minu jaoks. Ma leian, et meil on juba neid hallipassiomanikke ... minu jaoks on nad ühed immigrandid kõik. Meil on juba neid piisavalt, kellega tegeleda. 
See nüüd on näiteks jah siuke vabadus, mida ma tahaks mitte ainult isiklikel põhjustel, vaid üldises mõttes, et eesti rahvas oleks natuke rohkem kaitstud selle eest.

M: ... ei ela ma Eestis ja osaliselt ka sellepärast, et ma eelistan enda ümber näha natuke rohkem erinevusi. Diversiteeti. Siin see tänavapilt on ikka väga ühetaoline. Hästi ühemeelne, ühekeelne, ühevärviline, ühe ... Kõik on väga üks. See on natuke ... tähendab see ongi problemaatiline minu jaoks. Ja ma eelistan näha natuke rohkem kirevust. Kitsaks jääb, kui on ainult väga üks koridor, kust mööda kõndida.

„Vabaduste lugude“ videoklipid (kogukestus 135 minutit) on kunstnik Timo Tootsi lahendusena projitseeritud massiivse betoonekraani peale (foto 7). Sellele lisaks on ekraani ees jutumulli imiteerivad betoonistmed, millele on projitseeritud intervjuudest võetud tsitaadid juhuslikus järjekorras ning korraga eesti, inglise ja vene keeles. Tsitaadid vahetuvad pidevalt ning toimivad eeskätt pilgupüüdjana, kuid neil on videoklippidega koos töötades potentsiaal tuua välja uusi kihte ja arutluspunkte, kuna samal ajal esitatud erinevad ideed vabadusest saavad astuda dialoogi. Näiteks võib ilmuda külalise ette tsitaat: „See, et mina ei tunneta mingisugust vabaduse piiramist, näitab minu privilegeeritust ühiskonnas“, ning juhuse tõttu võib ekraanil olla samal hetkel intervjuu, kus samasoolises suhtes olev naine ütleb:

A: Ma arvan, et see põhiasi vabaduse juures ongi see, kui sa saad olla sina ise ilma tundmata hirmu. Ükskõik, kas siis tänaval või näiteks kui sa pead tööl varjama ... et kellega sa elad. [...] See võimalus. Võimalus olla sina ise. Inimesed [...], kellel ei ole sellist vastandumist ühiskonnaga, tihti nagu minu meelest ei saagi aru, et neil on tegelikult vabadus olla nemad ja ennast määratleda nii, nagu nad tahavad.

Foto 7

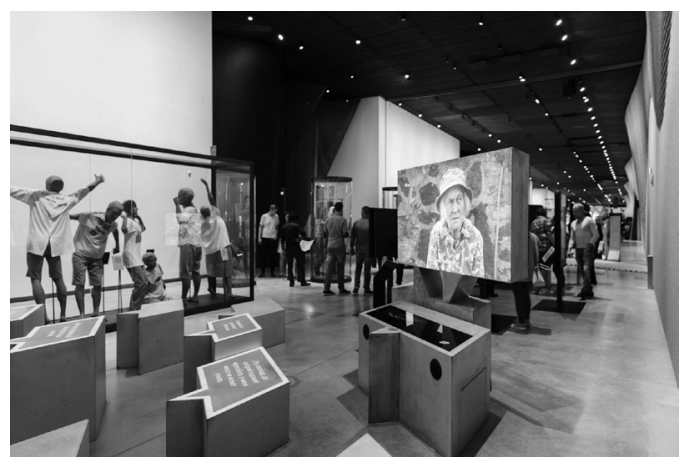


Selline ideede kombinatsioon on üks põgus ja juhuslik dialoog, mis hõlmab selliseid küsimusi nagu privileeg, võrdsus ja identiteet.

Potentsiaalselt toetab see ka mõistmise loomist arvamuste kaudu, mida on esitanud jagatud maailmavaate, kuid ebavorrdse sotsiaalse staatusega inimesed.

Mõlemad ülal esitatud näited dialoogist - nii teineteise arvamust oponeeriv kui toetav - on kombinatsioonid, mida külastaja ei pruugi kohata. Informantide J ja M intervjuud ei ole pandud teineteisele järgnema ning väljatoodud intervjuu ja tsitaat ei pruugi olla samal hetkel kuvatud, kuna video ja kirjalikud tsitaadid on esitlusfailidena iseseisvad ja omavahel sidumata. „Vabaduste lugude“ näol on tegu n-ö lugude kaleidoskoobiga, millel on sõnumikombinantsioonide edastamises lõpmatult variatsioone. Eksponaadist tuleb esile, et sellisel moel materjali kõrvutades saavad film ja seda saatvad tsitaadid olla vahendiks, et avastada ja uurida ühiskonnas esinevaid seoseid ja ühendusi. See sõltub aga külastaja valmisolekust neid leida.

Kuna esimesed intervjuud on tehtud juba üle viie aasta tagasi, on eksponaadi edasiarendamine üha enam päevakorral. Minu hinnangul oleksid praegu intervjueeritavate jutus tuntavalt valdavamad argielu aina tugevamast politiseerumisest tõukunud teemad, muu hulgas seoses näiteks prevaleeriva kliimadiskussiooni või paremradikaalsete vaadete levimisega valitsuses ja ühiskonnas. „Vabaduste lugude“ vorm lubab kergelt lisada uut materjali ning seetõttu näen võimalust muuta eksponaati aastate jooksul aina mitmekülgsemaks ja küpsemaks. Täispikad intervjuud arhiveeritakse ning need jäävad sel moel tulevastele põlvkondadele väärtuslikuks etnograafiliseks aineseks.

\section{Protsessid ja portreed}

Marko Raat jagab oma näitusefilmid kaheks laiaks kategooriaks: protsessi- ja portreefilmid. Protsessifilmid on vaatleva lähenemisega dokumentaalfilmid ning portreefilmid on ajalooliste sündmuste lavastused professionaalsete näitlejatega.

Marko Raadi protsessi- ja portreefilmid valmisid seitsme aasta vältel. Tema koostöö ERMi ja ka ERMi-väliste kuraatorite, teadurite ja koguhoidjatega kulmineerus suure hulga filmidega, mis täidavad näituse põhieesmärke ja toetavad külastajakogemust. Nagu näitusel tervikuna, ei ole ka Raat eesmärgiks võtnud tähistada suursuguseid ajaloosündmusi ja rahvuskangelasi. Selle asemel on ta keskendunud inimeste individuaalsetele lugudele ja argielulistele tegevustele. Raadi peamised loomingulised ja uurimuslikud küsimused puudutasid seda, kuidas esitada tihtilugu nähtamatuid ja tavalisi isiklikke lugusid nii, et need toetavad ja täiendavad üksteist (Raat 
2017). Olulised märksõnad tema teoste iseloomustamisel on sarnaselt „Vabaduste lugudega“ arvamuste ja elukogemuste paljusus.

Filmid on näituse kontekstis ebatavaliselt pikad ning rahuliku tempoga. Raadi ja näitusemeeskonna üks soov oli aeglustada näitusel liikumist ning filmides nähti abivahendit, kuidas kontrollida selle kiirust. Samas teadvustati näitusekülastaja ootust kiiresti tarbitava info järele.
Muidugi on pidevas lärmakas meediaväljas elaval inimesel automaatselt igav suhestuda ekraanidega, mis temaga karjudes ei suhtle. Me oleme kõik sellest pidevast mürast nii rikutud ja mõjutatud, et ei oska võib-olla esimestel sekunditel sellises harjumatus rollis introvertse ekraaniga suhestuda. Aga eesmärk oli kehtestada näitusel oma aegruum ja tempo, mis sihilikult ignoreerib pideva audiovisuaalse stimulatsiooni sõltuvust ja ei ekspluateeri näitusel külastaja esmaseid ihamootoreid. (Raat 2017)

Kui külastaja ei jää filme nende pikkuse ja tempo tõttu süvenenult vaatama, siis kontseptuaalselt on filmide vorm, sisu ja paigutus näitusel lahendatud nii, et isegi kui külastaja vaid minutiks ekraanide ees peatub, kuuleb ja näeb ta sellegipoolest fragmenditi representatsioone elatud eludest. Kui ta hetkekski ei peatu, saadavad fimide helid ja visuaalid teda siiski terve näituse vältel. ${ }^{3}$

\section{Protsessid}

Väljapaistvaim näide harjumatult pikast ja aeglase kulgemisega protsessifilmist on alanäitusel „Süüa me teeme“ eksponeeritud „Kassalint“, mis on 13-tunnine dokumentaalne vaatlus toodete asetamisest supermarketi kassalindile. Kuigi kohati õnnestub näha ka ostlejate käsi, siis peamiselt näeme vaid toodeid, mis aeglaselt mööda mehhaanilist linti liiguvad. „Kassalindil“ on esmalt keeruline vaatajat kaasa haarata, kuna tegu on niivõrd tavapärase nähtusega, kuid mida enam lindile laotatud esemeid jälgida, seda haaravam on kogemus. Nagu Raat märgib:

Mehaanilise lindi liikumise vaatamine on huvitav ja emotsionaalne kogemus. Kui vaadatavasse süvened, on seal

3 Kuna „Kohtumised“ on vormilt ja sisult suur näitus, siis võimaldamaks külastajal filme põhjalikumalt ja kiirustamata vaadata, valmivad Raadi filmidest ka kinoversioonid, mida külastaja saab tulevikus jälgida näituse kinosaalis. Sellist vajadust kinnitab ka käimasolev külastajauuring, millest joonistub välja, et filmid tõmbavad tähelepanu ning neid soovitakse pikemalt vaadata, kuid samas tuntakse vajadust näitusel siiski kiiremini edasi liikuda. (Aljas 2019) 
inimene oma valikute ja unistuste maailmaga. Iga toidukorv käivitab fantaasia, kes nende asjade taga on. Ja kui pikemalt vaatama jääd, hakkab õudne - kõik need päris toidust võõrandunud ja ebatervislikud kilenutsakad, liitrite viisi õlut, viina, limonaadi ja kurbi üllatusmune. (Raat 2017)

„Kassalint“ on huvitavas suhtes teise toidunäitusel eksponeeritud protsessifilmi sarjaga „Köögis“ (foto 8, 9), mis vaatleb professionaalsete Eesti toidupärandist inspireeritud tippkokkade päeva restorani köögis. Kvaliteetne ja hooajaline tooraine, maitseelamuse pakkumisele ja Eesti toidukultuuri väärtustamisele pühendunud toidutegemine ning kassalindil liikuvad tihtipeale läbimõtlemata ja ebatervislikud valikud on omavahel vastandatud ning sellega vestlusesse sätitud.
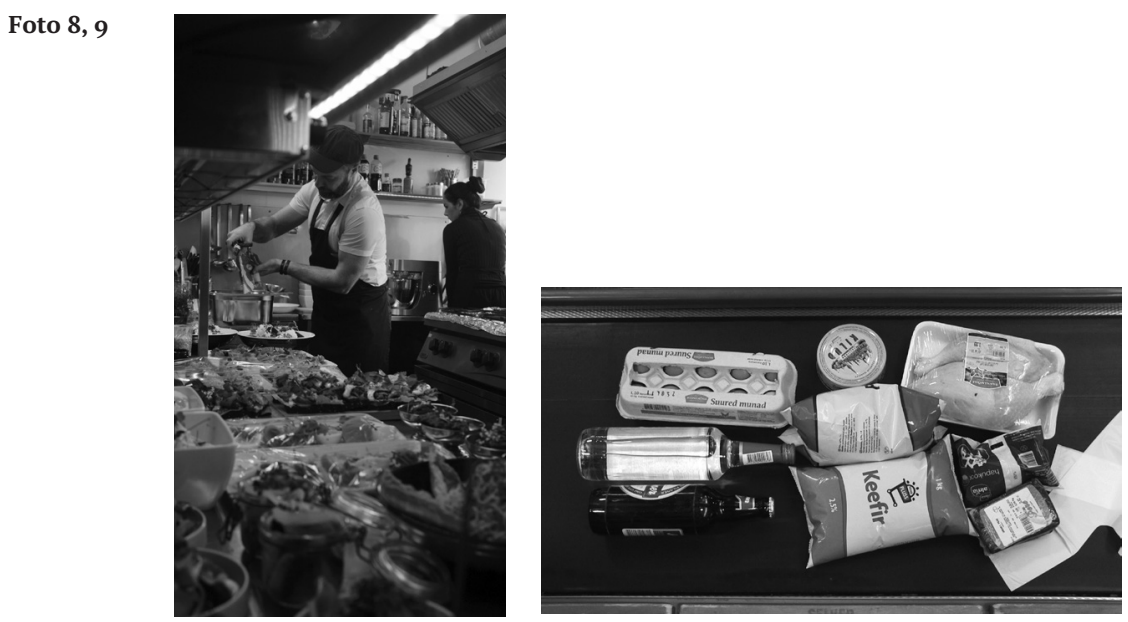

Kui „Kassalint“ ja „Köögis“ vaatlevad nüüdisaegsete trendide tõttu sündinud praktikaid, siis mitmed protsessifilmid uurivad traditsioonilisi kombeid ja tegevusi, mis on tänaseni kasutusel, kuid mida seostatakse üldiselt traditsioonilise talukultuuriga. ERMi audiovisuaalses arhiivis olevate materjalide kasutamise asemel loodi uus, et rõhutada nende oskuste ja tegevuste püsimist tänase päevani.

Alanäitusel „Talu elu ja talu ilu“ leiab rahvarõivavitriinide lähedalt ekraani, kus näeb Kihnu Roosit rahvarõivaid selga sättimas. Film „Riietumine“ (foto 10) heidab pilgu väikesesse, kuid väärtuslikku kultuurilisse ja sotsiaalsesse tegevusse. Siin tuleb välja ka järgmine oluline väärtus, mida näitusefilm saab pakkuda: vaadeldes näitusel eksponeeritud esemeid kasutaja ja kogeja pilgu läbi, saame ka selgema sissevaate nende esemete tähendusse. Esemete lugu saab nähtavaks just kasutaja perspektiivi kaudu.

Lisaks on kõnealusel alanäitusel eksponeeritud filmid, mis 
Foto 10

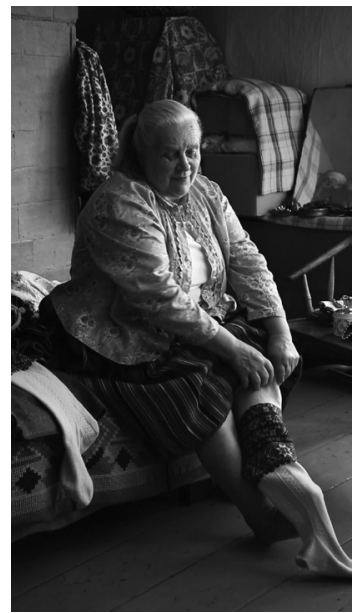

dokumenteerivad traditsioonilise talukultuuri tööprotsesse, mille etapid on jagatud kõrvuti asetsevate ekraanide vahel. Näiteks filmis „Vill“ (foto 11) demonstreeritakse lambapügamist, villa pesemist, kuivatamist ja töötlemist ning sellest lõnga tootmist. Esemed, mis on paigutatud ekraanide lähedale, pärinevad traditsioonilisest talukultuurist ning on osaliselt endiselt kasutusel. Eksponeerides traditsioonilisi esemeid ja tänapäeva elu käsitlevaid filme, demonstreeritakse rahvuslike tavade järjepidevust. Selliste filmide väärtus on muu hulgas hääbuvate kultuurinähtuste ja oskuste detailne jäädvustamine audiovisuaalse dokumenteerimise kaudu.

Foto 11

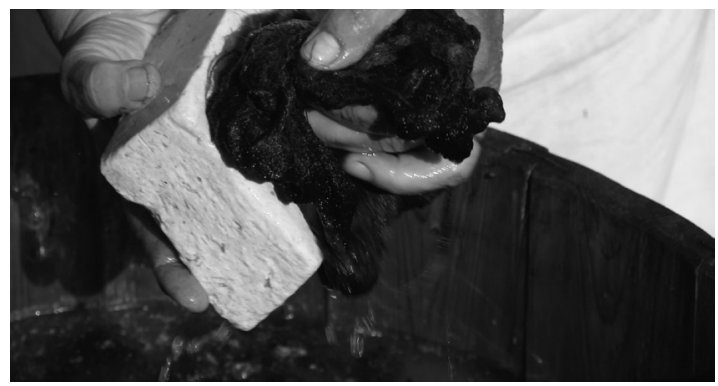

Erinevalt „Riietumisest“ keskendub kaamera vaid töövõtetele, kuid mitte inimesele. Suures plaanis on näha käsi ja materjale ning kogu protsessi on detailselt demonstreeritud. Taustainfot nende kaduvate töövõtete edasikandjate kohta aga ei ole. Raat selgitab, et mõned inimesed olid harjunud tegevust (turistidele) esitama rõhutatult, riietatuna Eesti talupojarõivastesse ning teised tegid tööd tavalistes tänapäevastes tööriietes: „Minu soovmõtlemine ja nägemus proovis [...] siis need kostüümid ja poosid võimalusel välja kadreerida ja keskenduda töövõtteid tõesti valdavatele kätele." (Raat 
2018) Keskendudes kätele, sai eklektilisest taustast stiililiselt ühtlane visuaal ning selle tõttu on muuseumikülastajat tõenäoliselt lihtsam protsessiga tutvuma haarata. ${ }^{4}$

Originaalne lahendus töövõtete kirjeldamisel on peaaegu kuus tundi kestev film „Kannatlikkuse proovikivi“ (foto 12), mis on eksponeeritud näituse kiviaega käsitlevas osas. Kuna aastatuhandete kaugusele jäävat kultuuri ei ole jäädvustatud ühegi visuaalse dokumendi abil ning argielu kohta teame vaid fragmente, siis oleks ka olemasoleva teadusliku teadmise põhjal olnud problemaatiline kasutada filmitegemisel lavastamist. Niisiis korraldati Tartu Ülikooli arheoloogia osakonna kursuse käigus eksperiment, et mõista kivikirvesse augu puurimise nüansse ning aja- ja energiakulu, kasutades selleks ise ehitatud kivipuuri ja kiviajast teada olevaid võtteid. See katse demonstreerib suurt jõupingutust, millega kiviaja inimesed silmitsi seisid. Kui üks puurija väsib, tuleb järgmine tema asemele, kuid ka tund hiljem ei paista auk märkimisväärselt sügavam.

Foto 12

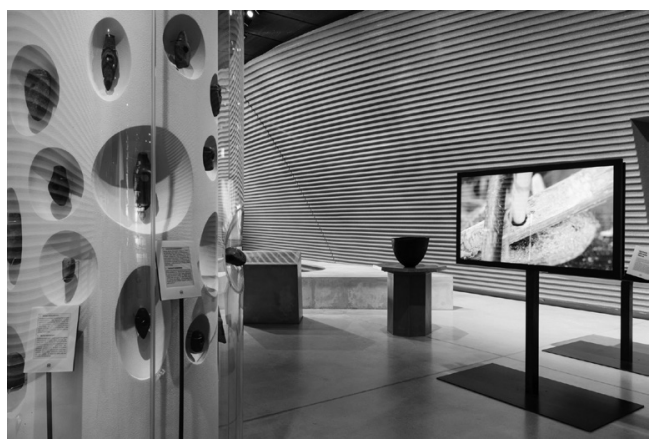

Eksponaadi kõrval on vitriinides hulk kiviaegseid varreauguga kirveid. Näitusefilmi ja originaalesemetega tutvumine annab külastajale vihjeid selle kohta, mida need ajaliselt kauged inimesed rutiinselt kogesid. Sellisel moel filmi ja esemete ühendamine muudab mõlemad eksponaadid kõnekamaks, kui need oleksid eraldi.

4 Kõnealuste filmide tootmise juures olnud kuraatorid kasutasid oma laia kontaktideringi, et leida filmis osalejad. Viimaste taust ja motivatsioon traditsiooniliste tööde tegemiseks oli aga erinev mõne jaoks oli see osa argipäevast, kuid teiste jaoks oli seal juures ka performatiivne mõõde, mis tähendas näiteks riietumist traditsioonilistesse rõivastesse publiku jaoks. Minu jaoks oleks huvitav näha filmides neid inimesi ühes oma erineva motivatsiooniga, kuid Raat soovis rakendada enda kontseptsiooni esitleda inimeste asemel tegevust. 


\section{Portreed}

Raadi portreefilmide allikaks on arhiivimaterjalid: kohtuistungite dokumendid, isiklikud kirjavahetused, mälestused, joonistused, fotod jne. Need filmid vaatlevad mineviku inimesi ja sündmusi ning on lavastatud professionaalseid näitlejaid rakendades. Portreefilmides esitavad näitlejad enamasti monoloogi, olles samal ajal ametis filmi teemaga seonduva tegevusega. Monoloogi kasutamine on läbiv seetõttu, et arhiivimaterjal on enamasti kirjutatud esimeses isikus ja dialooge esineb sellistes dokumentides harva.

Vertikaalsel ekraanil külastajaga vastamisi olev inimene vaatab rääkides otsa, räägib veenvalt, kuid laskumata liigsesse emotsionaalsusesse. Sarnaselt „Kohtumiste“ dokumentaalfilmidega on Raat hoidunud oma filmide kunstlikust dramatiseerimisest - kasutatud ei ole muusikat, et publiku emotsioone suunata, ega kaadritagust häält, et publikut informeerida sellest, kuidas filmi tuleb mõista. Käsitletavaid teemasid on vaadeldud erinevatest subjektiivsetest vaatepunktidest. Filmis „Revolutsiooni mälestused“ (foto 13, 14) saavad sõna kolm erineva etnilise ja sotsiaalse taustaga inimest: eestlasest aktivist, mõisateenija ja baltisaksa parun, kes räägivad oma kogemusest samal ajal kui 1905. aasta revolutsioon aset leiab. Kedagi neist ei kujutata vaenlasena, nad on tavalised inimesed oma isikliku agendaga.

Nagu protsessifilmides on ka portreefilmide tegelastel enamasti käsil nende lugudega seonduv tegevus ning mitmes portreefilmis on kasutatud protsessifilmi elemente. Näiteks Sindi villavabrikus töötanud lastest rääkivas filmis „Elu vabrikus“ on kasutatud vanu masinaid, millega näitlejad teevad villase lõnga valmistamise protsessi ka päriselt läbi ning räägivad samal ajal külastajale oma lugu.

Foto 13, 14
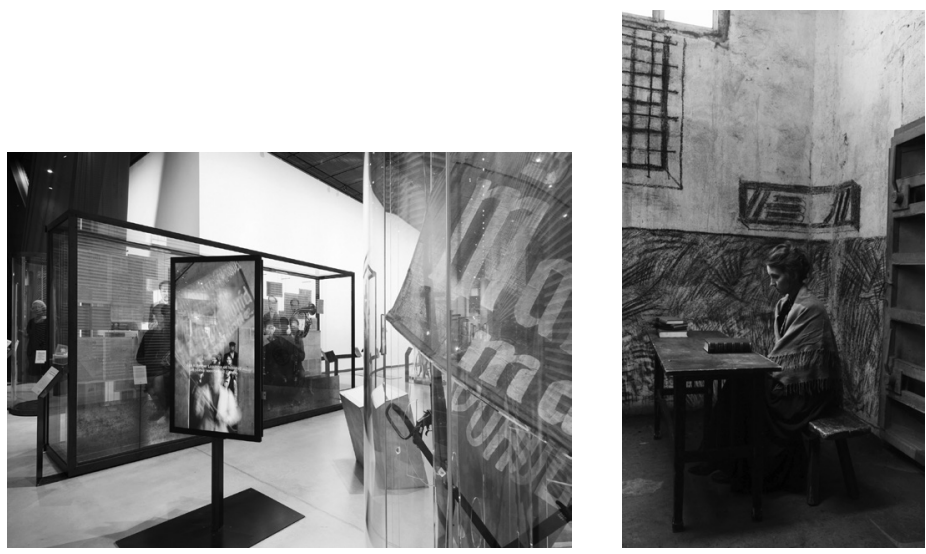
Ka lavastatud filmid on seotud nende lähedal eksponeeritud esemetega. Mitmed esemed, mida filmides kasutati, on autentsed ning kuuluvad ERMi kogudesse.

Originaalesemete kaasamine filmidesse teenis mitut eesmärki panna muuseumi enda kõige suurem vara, turvatud museaalid korraks taas asjana elama, anda neile füüsiliselt tagasi nende kasutuskontekst ning ühtlasi läbi selle ohu [esemeid kahjustada] teadvustada nende hindamatut ja unikaalset väärtust. (Raat 2017)

Kuigi filmides kasutati autentseid esemeid, on lavastatud filmid esteetiliselt tugevalt stiliseeritud ja kunstlikud, mis sihilikult vähendab riski, et filmi peetakse mineviku täpseks rekonstruktsiooniks. Näiteks näeme revolutsioonilippu vaid näiliselt lehvimas, kui revolutsionäär ühe koha peal sammub; mõisateenija sõidab jalgrattaga, mis tegelikult edasi ei liigu; villavabrikus on taustal suur endise villavabriku foto. Ajalooliste sündmuste kujutamine hõlmab endas mitut tõlgenduskihti: indiviidid dokumenteerivad enda vahetu subjektiivse kogemuse ning rohkem kui sajand hiljem loovad filmitegija ja kuraatorid selle dokumendi abil indiviidi kogemusest visuaalse representatsiooni. Mineviku visuaalse taasesitamise problemaatika tõttu ei saa olla üht tõetruud esteetilist rekonstruktsiooni. Kui esteetilised elemendid on selgelt stiliseeritud, mõistavad külastajad, et need filmid ei proovi olla täpsed ajaloolised rekonstruktsioonid (Raat 2017).

\section{Visuaalantropoloogiline lähenemine "Kohtumiste" filmides}

„Kohtumistele“ loodud dokumentaalfilmides leidub mitmeid antropoloogilisele filmile omaseid elemente. Erinevalt „Vabaduste lugudest" ei ole Marko Raat kasutanud visuaalantropoloogilisi meetodeid taotluslikult, kuid mitmed tema filmid lähtuvad neist siiski. Usutavasti on üks põhjustest see, et „Kohtumiste“ filmide lähteülesanne on olnud jutustada tavaliste inimeste argielulisi lugusid, keskendudes nende endi vaatenurgale. Mitmed visuaalantropoloogia metodoloogilised küsimused tegelevad selle ülesandega süvitsi.

On väärtuslik, et audiovisuaalsete vahenditega on loodud etnograafilist teadmist. Olulist ja mitmekülgset uurimismaterjali tänapäeva elust ja hoiakutest pakuvad muu hulgas nii „Vabaduste lood“ kui ka „Kassalint“, kuigi nende kontekstualiseerimise tase on väga erinev. Esimese väärtus on individuaalsed lood tänapäevast 
ja minevikust ning teise oma kvantitatiivne materjal tänapäevase tarbimiskultuuri kohta.

„Vabaduste lood“ kasutavad visuaalantropoloogias levinud videointervjuu meetodit ning oluline on olnud filmitavaga usaldava suhte loomine. Seetõttu olen teinud välitöid üksi, et vähendada informandi võõristust ning luua isiklikest vaadetest rääkimiseks rahulik ja usalduslik keskkond. Monteerimisel olen valinud intervjuudest lõigud, mis kirjeldaksid iseseisvalt ja dialoogis teiste intervjuudega vabadust võimalikult mitmekülgselt. Teisalt olen valitud materjali teinud võimalikult vähe lõikeid, et intervjueeritava räägitud lugu moonutusteta näitusekülastajani jõuaks.

Marko Raadi protsessifilmid on tehtud väikese võttemeeskonnaga ning kasutatud on vaatlevale antropoloogilisele filmile omaseid pikki kaadreid, monteerimisel on materjali tehtud vähe lõikeid, lisatud ei ole kaadritagust teksti, mis tegevuse lahti seletaks. Filmides puudub ka ilmne dramaatilisus ning protsesse jälgitakse detailselt.

Näitusel eksponeeritud lavastatud filmid eemalduvad sihilikult elutruudusest, kuna vastasel juhul võivad filmid „külastaja kujutluse ajaloost selle stimuleerimise ja vabastamise asemel koloniseerida“" (Kaes 1990: 118, viidatud Baer 2001: 493 kaudu). Raadi lähenemisel on sarnaseid elemente antropoloog Franz Boase kriitikaga dioraamide kohta, mis olid eksponeeritud Ameerika Loodusmuuseumis 20. sajandi alguses. Boas tegi ettepaneku jätta dioraamide kunstlikkus teadlikult ilmseks, et vähendada objektiivse tõe illusiooni tekkimise riski. Nagu kirjeldab Alison Griffiths:

Boas toetas antirealistlike konventsioonide kasutamist, mis annaks edasi pigem üldist pedagoogilist muljet kui täielikku ehtsust. Selle asemel, et üritada loodust kopeerida, tundis Boas, et parem on rõhutada väljapaneku kunstlikku loomust. [...] Hirm, et dioraamide illusionistlik lumm võib tuimestada muuseumikülastajate meeled pedagoogika vastu, ilmnes taas hilisemates debattides etnograafilise filmi üle, kuna antropoloogid kartsid, et filmid võivad samamoodi anda privileegi vaatemängule ratsionaalse kaasamise asemel. (Griffiths 2002: 24)

Boas ei soovinud pedagoogilise eesmärgi mattumist vaatemängulisuse alla, kuid Raat väljendab üleüldist skepsist pealesurutud otsese pedagoogilise efekti suhtes:

Sindi vabriku lapstööline suhtleb külastajaga emantsipeerunud ja enesekindla 196ondate Pariisi tudengi positsioonilt; maagilise mõtlemise aegne nõiaprotsess ja külaklatš rullub lahti 


\begin{abstract}
Ameerika kohtudraamana; 1905 revolutsiooni sündmustest rääkides istutakse moodsates 197ondate toolides jne. Visuaal on rõhutatult esteetiline, kuid samas lakooniline ja eklektiline, sise- ja väliruumid on sihilikult sassis, sisaldades teadlikult meie kaasajast pärit rekvisiite ja žeste, mis peavad lõhkuma nn kinematograafilise ajalootõe illusiooni. [...] Nende ekraanide kunstilise kujundi keskne ja maaliline visuaal välistab kiire pedagoogilise ja informatiivse esmatasandi. (Raat 2017)
\end{abstract}

Selline kunstiline võte annab külastajale mõista, et filmidel on autor, kelle peegeldus on iga stiliseeritud ja rõhutatult esteetilise elemendi taga. Kunstiline teostus ei taotle objektiivse tõe representeerimise teenimist. Nagu sissejuhatuses mainitud, on arusaamad objektiivse representatsiooni võimalikkusest vananenud ning võte on pigem kooskõlas nüüdisaegse visuaalse ja sensoorse antropoloogia ideega „mitte rääkida, vaid kutsuda kujutlema“ (Cubero 2020).

Potentsiaalselt muudetakse kasutatud lähenemiste abil oluliseks eelkõige lugu ise ja inimene ekraanil ning külastajale antakse võimalus kujutleda neid lugusid iseseisvalt. Nagu mainitud, on just külastaja aktiivne interpretatsioonivõimalus „Kohtumistel“ läbivaks eesmärgiks ning näitusele loodud teostes kasutatud antropoloogilise filmi elemendid toetavad seda eesmärki.

\title{
Kokkuvõte
}

ERM on välitöödel 1960. aastatest tootnud dokumentaalset filmimaterjali, kuid kuni uue hoone ja püsinäituste avamiseni jäi filmi eksponeerimine näitustel marginaalseks. ERMi uue maja püsinäitusele „Kohtumised“ loodud dokumentaalsed ja lavastatud filmid panustavad aga olulisel määral näituse visuaalse ja sisulise identiteedi loomisse.

Filmid, mille on loonud režissöör Marko Raat (Allfilm) ja vähemal määral käesoleva artikli autor, moodustavad näitusesaalis ühes vitriinidega visuaalse rütmi ning saadavad külastajat pildi ja heliga terve näituse vältel. Presenteerides mitmekesiseid vaatenurki ning lõimituna ümbritsevate eksponaatidega, on filmidel võimaldatud nähtavalt ja kuuldavalt ühineda dialoogidega, mida „Kohtumised“ soovib tekitada. Kui traditsiooniliselt on muuseumifilmid ja eksponaadid olnud rangelt kureeritud ning kuraatorid-filmitegijad on hoidnud enda käes võimu teadmiste loomisel ja presenteerimisel, siis nüüd on muuseumikülastaja roll materjalide mõtestamisel üha aktiivsem. 
Filmid kutsuvad kujutlema nüüdisaegsete ja minevikus elanud inimeste kogemusi, kasutades selleks mitmeid visuaalantropoloogiale omaseid meetodeid ja temaatikat. „Kohtumiste“ filmides võimaldatakse mõtestada inimeste lugusid ja neid ümbritsevat maailma nende endi vaatenurgast. Arvestatav osa „Kohtumiste“ filmimaterjalist on mitmekülgne etnograafiline uurimismaterjal, mille väärtus ajaga kasvab. Filmid on aeglase kulgemisega, sunnitud draamata ja pika kestusega teosed, mis pakuvad nii väljakutset kui ka võimalust süveneda. Nagu tänapäeva antropoloogilisele filmile kohane, ei ole kasutatud diktoriteksti ega muusikat, mis dikteeriksid sisu mõistmist ja suunaksid emotsioone.

Lavastatud, arhiiviallikatel põhinevad filmid kasutavad esteetilise lahendusena eklektilist ja stiliseeritud vormi, mitte võimalikult täpset ajaloolist rekonstruktsiooni. Nii vähendatakse sihilikult riski, et filmi peetakse ajaloo tõetruuks taasesituseks, ning külastajad saavad sündmusi iseseisvalt kujutleda, olemata kammitsetud liigsest pedagoogilisest sekkumisest.

„Kohtumiste“ filmid ei ole vaid esemete juurde loodud illustreeriv materjal, vaid need täidavad nii eraldiseisvalt kui ka esemetega seosesse sätituna mitmeid eesmärke. Filmid näitlikustavad originaalesemete kasutuskonteksti ning näitavad selle kasutaja perspektiivi, panevad elama nii esemed kui ka kirjalikud arhiiviallikad ja pakuvad võimalust avastada seoseid ja ühendusi, mis eraldiseisvana ei tuleks nähtavale, andes aimu nii aastatuhandetetagustest argielu kogemustest kui ka tänapäeva argitegevustest. Filmide keskmes on eelkõige Eesti alal minevikus elanud ja tänapäeval elavad inimesed, kellel on oma subjektiivsed vaated ja ainulaadne elukogemus ning kelle kaudu saab näitusekülastaja sissevaate inimesi ümbritsevale laiemale kultuurilisele ja ühiskondlikule kontekstile. 


\section{KARIN LEIVATE GIJA (MA) on visuaalantropoloog ja näitusekuraator. Ta on omandanud magistrikraadi kultuuriantropoloogias Eesti Kunstiakadeemias (2012) ning visuaalantropoloogias Manchesteri Ülikoolis (2014). Leivategija töötab teadur- kuraatorina Eesti Rahva Muuseumis ja on Maailmafilmi festivali programmikuraator. Tema peamised uurimisteemad puudutavad ööelu etnoloogiat, elulugusid ja noortekultuuri. Ta otsib viise, kuidas visuaalantropoloogilist lähenemist integreerida nii konventsionaalsete kui ka loomingulisemate uurimis- ja eksponeerimismeetoditega.}

\section{Allikad}

Aljas, Agnes. 2019. Eesti Rahva Muuseumi siseseminari ettekanne, 2.10.2019.

Cubero, Carlo. 2020. Eesti Rahva Muuseumi siseseminari ettekanne, 14.02.2020.

Leivategija, Karin, rež. 2016. Vabaduste lood. Film näitusel „Kohtumised“. Eesti Rahva Muuseum. $135 \mathrm{~min}$.

Raat, Marko, rež. 2016. Revolutsiooni mälestused. Film näitusel „Kohtumised“. Allfilm OÜ. 33 min.

Raat, Marko, rež. 2016. Kassalint. Film näitusel „Kohtumised“. Allfilm OÜ. 825 min.

Raat, Marko, rež. 2016. Riietumine. Film näitusel „Kohtumised“. Allfilm OÜ. $28 \mathrm{~min}$.

\section{Kirjandus}

Baer, Alejandro. 2001. Consuming history and memory through mass media products. - European Journal of Cultural Studies 4 (4): 491-501.

Cameron, Duncan F. 1971. The Museum: A temple or the forum. - Curator: The Museum Journal 14 (1): 11-24.

Delgado, Elena. 2009. Museums as spaces of negotiations. - Museums as Places for Intercultural Dialogue: Selected Practices from Europe. Toim Simona Bodo, Kirsten Gibbs, Margherita Sani. MAP for ID, 8-9.
Raat, Marko, rež. 2016. Elu vabrikus. Film näitusel „Kohtumised“. Allfilm OÜ. 17 min.

Raat, Marko, rež. 2016. Kannatlikkuse proovikivi. Film näitusel „Kohtumised“. Allfilm OÜ. $340 \mathrm{~min}$.

Raat, Marko, rež. 2016. Vill. Film näitusel „Kohtumised“. Allfilm OÜ. 27 min.

Raat, Marko. 2017. Karin Leivategija elektrooniline kirjavahetus filmitegijaga. 13.06.2017.

Raat, Marko. 2018. Karin Leivategija elektrooniline kirjavahetus filmitegijaga. 31. 01.2018.

Griffiths, Alison. 2002. Wondrous Difference. Cinema, Anthropology \& Turn-of-the-Century Visual Culture. New York: Columbia University Press.

Griffiths, Alison. 2013. Camping among the Indians: Visual Education and the Sponsored Expedition Film at the AMNH. - Recreating First Contact: Expeditions, Anthropology, and Popular Culture. Ed. by Joshua A. Bell, Alison K. Brown, Robert J. Gordon. Washington D.C.: Smithsonian Institution Scholarly Press, 90-108. 
Henning, Michelle. 2005. Museums, Media and Cultural Theory. Maidenhead: Open University Press.

Jørgensen, Anne Mette. 2018. Introduction Anthrovision 6.1. http://journals.openedition. org/anthrovision/3005. (Viimati külastatud 6.11.2019.)

Kaes, Anton. 1990. History and film: Public memory in the age of electronic dissemination. - History and Memory 2 (1): 111-129.

MacDougall, David. 1997. The visual in anthropology. - Rethinking Visual Anthropology. ToimMarcus Banks, Howard Murphy. New Haven; London: Yale University Press, 276-295.

MacDougall, David. 2006. The Corporeal Image: Film, Ethnography, and the Senses. Princeton and Oxford: Princeton University Press.

Pink, Sarah. 2007. Doing Visual Ethnography. London: SAGE.
Rattus, Kristel. 2016. Dialoogilisus Eesti Rahva Muuseumi püsinäitusel „Kohtumised“. - Eesti Rahva Muuseumi aastaraamat 59. Toim Pille Runnel, Agnes Aljas. Tartu: Eesti Rahva Muuseum, 143-159.

Runnel, Pille; Krista Lepik; Pille Pruulmann-Vengerfeldt. 2014. Visitors, users, audiences: Conceptualising people in the museum. - Democratising the Museum: Reflections on Participatory Technologies. Toim Pille Runnel, Pille Pruulmann-Vengerfeldt. Bern: Peter Lang Verlag, 219-240.

Toulouze, Eva; Liivo Niglas. 2009. Etnograafiline film Eestis 1960-8o: Eesti Rahva Muuseumi filmitoodang. - Worldfilm. Maailmafilm. Tartu visuaalse kultuuri festival 23.-29. märtsini. Tartu Festival of Visual Culture March 23th-29th. Toim Pille Runnel. Tartu: Eesti Rahva Muuseum; Maailmafilmi Ühing, 102-104. 


\title{
Films in the Estonian National Museum's permanent exhibition 'Encounters'
}

\author{
Karin Leivategija
}

The world's first film specifically produced for an exhibition was displayed in the American Museum of Natural History back in 193o. In the 1960s the Estonian National Museum also began to collect actively ethnographic film material during fieldwork, but its use in exhibitions was marginal. The films at the museum's new permanent exhibition, 'Encounters', however, contribute significantly to the visual and content identity of the display and invite visitors to engage in a social and cultural dialogue. Along with the showcases, the films create a visual rhythm in the display hall, and their visuals and sound accompany visitors throughout the entire exhibition. By virtue of presenting diverse perspectives and their integration with the surrounding display, the films can visibly and audibly join in the discussions that 'Encounters' seeks to elicit.

The films of 'Encounters' focus on the past and present inhabitants of the territory of Estonia, primarily, who have their subjective views and particular life experience and through whom an exhibition visitor can gain an insight into the broader cultural and social context.
If in the past, museum films and display items were strictly curated, with the power to create and distribute knowledge concentrated in the hands of curators-filmmakers, then at present the role of museum visitors examining the material has increasingly become more active. Without a recourse to the voice-over or music, which prescribe to the visitors how they should perceive and construe the content, visitors can experience and decipher the films independently. Without the curator's direct didactical intervention, visitors are free to assign a personal meaning to the themes presented. The films of 'Encounters', which are unconventionally slow and long-lasting for contemporary people, offer a challenge and opportunity for thoughtful reflection.

My own video exhibit 'Stories of Freedom', which presents the thoughts of nearly 80 inhabitants of Estonia on the subject of freedom in the form of videotaped interviews and written citations, explores meanings and ideas that are abstract and nonmaterial but universally inherent to human beings. The documentaries of Marko Raat take a detailed look at various processes and work techniques from traditional as well as modern life. His films deal with 
some cultural practices that are still in use but inevitably vanishing as well as some contemporary practices such as a day at a supermarket checkout belt, or activities in the kitchens of top chefs.

Raat's scripted portrait films summon up the lives of people from the past. By his use of aesthetically eclectic and stylised form instead of maximally accurate reconstruction, the filmmaker deliberately minimises the possibility of the films being seen as accurate representations of history. Although the films are not historically faithful depictions in terms of their aesthetics, Raat has used archival documents and authentic museum objects as the films' source material. Thus, by building on historical documents and objects, he has created characters who tell their real-life stories on the vertical screens, look into the eyes of the visitors and go about their business. The text of archival documents has been brought to life in a historical re-enactment, and the use of authentic objects illustrates the context in which these objects were originally used.

When film is integrated with other materials, such as written citations in the video exhibit 'Stories of Freedom' or traditional costumes in the film 'Clothing', we are able to detect connections and associations which would not have emerged in isolation. By observing the exhibited items through the perspective of the people who have used and experienced them, such as the traditional dress that an elderly lady from the island of Kihnu puts on, we can also sense more keenly the meaning of these objects. Their story becomes visible through the perspective of the user.

The exhibition films can also efficiently describe daily life from thousands of years ago, of which there are no visual records. For instance, the experiment of grinding a stone axe in the film 'Touchstone of Patience', gives us a sense of what people in the Stone Age had to routinely endure. Combining film with some authentic stones exhibited nearby, enhances the communicative potential of each exhibition item which would not be as great without such a juxtaposition.

Traditional work practices, goods placed on the supermarket checkout belt, thoughts on freedom expressed by people with different age, social and cultural backgrounds comprise an important ethnographic material which will unlock stories of modern Estonia in a diversified and polyvocal manner in the future as well. 


\section{Фильмы на постоянной экспозиции Эстонского национального музея «Встречи»}

Карин Лейватегия

Первый в мире фильм, снятый специально для выставки, был показан в Американском музее естественной истории ещё в 1930 году. В 1960-е годы Эстонский национальный музей также стал активно заниматься сбором полевого этнографического видеоматериала, однако на выставках он использовался мало. На постоянной экспозиции «Встречи» в новом здании Эстонского национального музея фильмы стали значительной составляющей визуальной и содержательной идентичности выставки, призывая посетителей к участию в социально-культурном диалоге. Вместе с витринами фильмы подают визуальный ритм в выставочном зале, а видеокадры и звук сопровождают посетителей на протяжении всей выставки. Демонстрируя разнообразные взгляды и будучи интегрированными с окружающими экспонатами, фильмы зрительно и слышимо участвуют в дискуссии, развёрнутой «Встречами».

\section{Центральное место в} фильмах «Встреч» занимают люди, жившие в прошлом и проживающие сейчас на территории Эстонии, со своими субъективными взглядами и исключительным жизненным опытом. Через них посетителям выставки предлагается экскурс в окружающий нас широкий общественно-культурный контекст.

Раньше музейные фильмы и экспонаты строгим образом курировались, кураторы-создатели фильмов имели контроль над созданием и распределением знаний. Теперь же посетители музея имеют возможность активно знакомиться с материалами. Они могут самостоятельно просматривать и осмысливать музейные фильмы, без текста диктора и музыки, подсказывающих, как следует понимать содержание и что посетитель должен чувствовать. Без прямого дидактического вмешательства куратора посетитель может сам придать представленным темам свой личный смысл. Фильмы на «Встречах», непривычно длинные и тянущиеся для современного человека, являются как вызовом, так и возможностью углубиться в тему.

В моём видео-экспонате «Истории свободы», где в форме интервью и цитат представлены размышления почти 8о человек о свободе, рассматриваются нематериальные и абстрактные, 
но в то же время универсальным образом присущие людям смыслы и мысли. В документальных фильмах Марко Раата детально обозреваются процессы и занятия как в традиционной, так и в современной жизни. В них рассматриваются культурные практики, бытующие и сегодня, но уже неизбежно меркнущие. Также в них описываются сегодняшние практики, например один день из жизни кассовой ленты в одном из супермаркетов или работа первоклассных поваров на кухне.

В постановочных фильмахпортретах М. Раата представлены судьбы людей прошлого.

Намеренное использование автором стилизованной и эклектичной в эстетическом смысле формы вместо максимально точной реконструкции снижает риск того, что фильм будет воспринят в качестве достоверного воспроизведения истории. Несмотря на то, что в художественном плане эпоха в фильмах показывается недостоверно, в них использованы архивные документы в качестве источников и представлены аутентичные предметы из фондов музея. Опираясь на исторические документы и музейные предметы, были созданы герои, которые делятся на выставке своими реальными историями, глядя на посетителей с вертикальных экранов и занимаясь в то же время своими делами. В исторических постановках оживают тексты архивных документов, а использование оригинальных экспонатов делает наглядным первоначальный контекст применения предметов.
В комбинациях, рождающихся в результате интеграции фильмов с другими материалами, такими как проецирование цитат в «Историях свободы» или народные костюмы в фильме «Одежда», раскрываются различные связи и сочетания, которые не проявились бы в отдельности. Видя представленные на выставке предметы глазами тех, кто знает и использует их, например, облачение Кихну Роози в народную одежду - мы можем лучше понять значение этих предметов. Истории экспонатов раскрываются через призму взглядов их пользователей.

Кроме этого, в выставочных фильмах эффектно описывается будничная жизнь тысячелетней давности, о которой мы не имеем никаких визуальных документов. Например, из эксперимента по изготовлению каменного топора в фильме «Пробный камень терпения» мы можем получить представление о рутинном труде людей каменного века. Фильм и экспонируемые там же аутентичные камни вместе становятся красноречивее, нежели если бы они были представлены отдельно.

К слову сказать, традиционные занятия, товар на кассовой ленте современного супермаркета, мысли людей разного возраста, с разным социальным и культурным опытом о свободе являются важным этнографическим материалом, который и в будущем с разных сторон и на разные голоса будет представлять истории о сегодняшней Эстонии. 